\title{
Kinerja Quagga pada Routing BGP IPv6 Menggunakan Metode Dual Stack
}

\section{Performance of Quagga on BGP IPv6 Routing Using Dual Stack Method}

\author{
Andi Kriswantono*1, Arief Setyanto ${ }^{2}$, Suwanto Raharjo ${ }^{3}$ \\ ${ }^{1,2}$ Teknik Informatika, Universitas Amikom Yogyakarta, ${ }^{3}$ Teknik Informatika, Institut Sains \& \\ Teknologi AKPRIND Yogyakarta \\ E-mail: *1andi.kriswantono@students.amikom.ac.id, ${ }^{2}$ arief_s@amikom.ac.id, \\ ${ }^{3}$ wa2n@akprind.ac.id
}

\begin{abstract}
Abstrak
Alamat jaringan yang digunakan saat ini adalah IPv4 (Internet Protocol v4), perkembangan jaringan menuju IoT (Internet of Think) meningkatkan kebutuhan akan alamat IP (Internet Protocol. Solusi terkait masalah IP adalah dengan melakukan migrasi ke alamat IPv6 (Internet Protocol Version 6). Metode transisi IPv4 ke IPv6 menggunakan Dual Stack merupakan metode yang paling baik dan stabil untuk dapat diimplementasikan. Salah satu pertimbangan dari provider penyedia jasa dan jaringan internet dalam melakukan migrasi ke jaringan IPv6 adalah terkait dengan kinerja BGP (Border Gateway Protocol) yang merupakan routing pondasi terbentuknya internet. Hal ini terkait dengan besarnya rute dengan adanya IPv6 yang nantinya mengakibatkan besarnya konsumsi CPU, memori dan lamanya BGP dalam menerima table routing secara penuh (convergence). Salah satu software routing BGP yang popular dan banyak digunakan di jaringan adalah menggunakan Quagga routing. Hasil dari penelitian ini menunjukkan bahwa penggunaan Quagga dalam menangani 10 peer BGP IPv4 dan IPv6 menunjukkan hasil yang baik, router membutuhkan waktu 106,6 second atau kurang lebih 1 menit 7 detik dengan konsumsi CPU maksimal 18,54\% dan konsumsi memori 16,45\% untuk dapat menerima seluruh table routing.
\end{abstract}

Kata Kunci - Ipv6, Dual Stack, Quagga, BGP routing, convergence

\begin{abstract}
The current network address is IPv4 (Internet Protocol v4), network development towards IoT (Internet of Think) increases the need for IP addresses (Internet Protocol). The solutions of IP problem are to migrate to IPv6 (Internet Protocol Version 6) addresses. IPv4 to IPv6 transition method using Dual Stack is the best and most stable method to implement. One of the considerations of internet service provider in migrating to IPv6 network is related to BGP (Border Gateway Protocol) performance that is the foundation routing internet connection. This is related to the magnitude of the route with the IPv6 which will result in the amount of CPU consumption, memory and the length of BGP in receiving the full table routing (convergence) One of the popular and widely used BGP routing software on the network is using Quagga routing. The results of this study show that using Quagga in handling 10 BGP IPv4 and IPv6 peers shows good results, the router takes 106.6 seconds or approximately 1 minute 7 seconds with a maximum CPU consumption of $18.54 \%$ and memory consumption of $16.45 \%$ to be able to accept all routing tables.
\end{abstract}

Keywords — Ipv6, Dual Stack, Quagga, BGP routing, convergence 


\section{PENDAHULUAN}

Perkembangan teknologi jaringan komputer saat ini semakin pesat seiring dengan kebutuhan masyarakat akan layanan yang memanfaatkan jaringan internet. Alamat jaringan yang umum digunakan saat ini adalah IPv4 (Internet Protocol version 4), disadari ataupun tidak kebutuhan akan alamat IP (Internet Protocol) terus meningkat. Kebutuhan akan alamat IP pada perkembangannya tidak hanya untuk perangkat komputer saja akan tetapi telah berkembang menuju IoT (Internet of Things) yang mana semua perangkat nantinya akan dapat dikendalikan menggunakan jaringan internet, organisasi IEEE (Institute of Electrical and Electronics Engineers) memperkirakan pada tahun 2020 akan mencapai kurang lebih 50 milyar perangkat IoT yang saling terhubung [1].

Kenyataan yang dihadapi dunia saat ini adalah semakin menipisnya alamat IPv4 yang dapat dialokasikan. Saat dokumen ini dibuat informasi dari situs resmi APNIC (Asia-Pasific Network Information Center) yaitu organisasi yang menangani distribusi alamat IP Asia Pasific bahwa APNIC melakukan kebijakan dengan membatasi permintaan IPv4 dengan hanya mengakomodir maksimal /22 kerena ketersediaanya yang semakin menipis dan harus segera implementasi IPv6 (Internet Protocol Version 6) [2][3]. Saat ini penyedia jasa layanan internet masih bertahan menggunakan NAT (Network Address Translation) yang memungkinkan banyak user dapat terhubung ke internet menggunakan satu alamat IP public yang banyak kelemahannya salah satunya adalah terkait pelacakan keaslian sumber data.

Proses migrasi dari jaringan IPv4 menuju ke jaringan IPv6 secara teknis tidak mudah untuk dilakukan. Pada tahun 2014 pemerintah membuat aturan melalui Peraturan Menteri No13 tentang kebijakan roadmap penerapan IPv6 di Indonesia yang didalamnya sudah mengatur tentang roadmap dan target kerja yang harapannya transisi IPv4 ke IPv6 dapat segera direalisasikan [4]. Akan tetapi hingga saat ini kemampuan penyerapan IPv6 di Indonesia masih 0.08\% dari total penggunaan internet global [5]. IPv6 menghasilkan performace delay yang lebih tinggi dibandingkan dengan IPv4 [6]. Dalam perkembangannya transisi IPv4 terdapat 2 metode yang umum dan popular digunakan untuk transisi IPv4 ke IPv6 yaitu menggunakan metode Dual Stack dan metode Tunneling. Metode transisi menggunakan Dual Stack merupakan metode yang paling baik dan stabil untuk dapat diimplementasikan akan tetapi lebih boros dalam penggunaan CPU dan memori [7][8].

Salah satu pertimbangan dari provider penyedia jasa dan jaringan internet dalam melakukan migrasi jaringan adalah terkait dengan kinerja BGP (Border Gateway Protocol) yang merupakan routing paling penting diinternet, isu yang muncul terkait kemampuan BGP adalah dalam hal kemampuan menangani besarnya rute yang diakibatkan adanya IPv4 dan IPv6. Pada jaringan IPv4, BGP membutuhkan waktu yang cukup lama agar dapat melakukan update table routing (convergence) dan membutuhkan konsumsi memori dan CPU yang cukup besar [9] [10]. Dengan mengetahui pentingnya penggunaan $B G P$ dalam hal konektivitas internet sehingga perlu diketahui pula tentang kinerja routing $B G P$ agar dapat digunakan untuk menimalkan terjadinya resiko kegagalan dalam implementasi jaringan IPv6.

BGP secara de facto merupakan protokol routing standar yang bertujuan untuk memilih jalur-jalur interdomain. BGP merupakan prefix-based path-vector protocol yang dijelaskan dalam [11] dan telah dilakukan pengembangan [12] yang menjelaskan implementasi report pada BGP4. Fungsi utama dari BGP adalah untuk mempertukarkan network reachability information antar suatu BGP router dengan BGP router yang lain. Dalam informasi ini terdapat juga informasi jumlah AS (Autonomous System) yang berada dalam jalur penyampaian informasi tersebut. Dengan adanya informasi ini, dapat dibentuk grafik dari AS path yang saling terkoneksi sehingga dapat menghindari terjadinya routing loop. Selain fungsi di atas, BGP juga digunakan untuk menerapkan policy routing di tingkat interdomain.

BGP routing protocol merupakan protocol yang lambat dalam konvergensi, banyak aplikasi di internet mengalami delay karena konvergensi BGP [9]. Penelitian ini dilakukan dengan menggunakan BGP IPv4 dengan tujuan untuk memberikan gambaran tentang upaya untuk meningkatkan kinerja routing interdomain. Penelitian ini menghasilkan beberapa pendekatan 
tentang perbaikan kinerja BGP yaitu mempercepat table routing update, membatasi eksplorasi jalur, policy konfigurasi yang efisien, BGP multipath dan kontrol jaringan yang terpusat. Dari penelitian ini peneliti mengharapkan arah penelitian berikutnya tentang BGP yaitu mengembangkan mekanisme yang tidak mengarah pada penggantian arsitektur protocol, mengembangkan mekanisme yang tidak menghambat kebijakan BGP. Dengan semakin banyaknya rute di internet tentu saja semakain memperlambat proses konvergensi BGP, menurut [10] lambatnya konvergensi BGP diakibatkan semakin banyaknya rute yang tersedia di internet sehingga dapat mengakibatkan flapping route yang dapat mengganggu kinerja jaringan. Akan tetapi di satu sisi banyaknya rute diinternet juga diperlukan misalnya dalam penggunaan multihomed sehingga apabila penggunaan primary link terjadi gangguan dapat menggunakan secondary link. Salah satu protokol routing yang melakukan proses pencarian rute dengan rentan waktu lama adalah dynamic source routing (DSR), terdiri atas dua bagian, route discovery dan route maintenance [13].

Dual stack memiliki performa yang terbaik dibanding dengan metode transisi yang lainnya akan tetapi dalam prosesnya mengkonsumsi lebih banyak sumber daya memori dan CPU karena mengelola dua kali lebih banyak alamat IP agar dapat bekerja dengan baik [7]. Metode transisi dual stack diperkenalkan oleh IETF bersama dengan metode tunneling [14] dan selanjutnya mengalami pengembangan [15] dengan metode ini memungkinkan baik protokol IPv4 maupun IPv6 ada dalam device dan network yang sama. Menurut [16] metode dual stack dalam hal QOS (Quality of Service) dengan parameter troughput, delay dan packet loss pada transter data 10MB mendapatkan hasil dengan kategori baik berdasarkan standarisasi TIPHON. IPv6 merupakan teknologi baru sehingga dalam rencana transisi untuk menggantikan IPv4 harus menjaga agar performa jaringan tidak menurun, dalam penelitian. Pengujian jaringan IPv6 menggunakan metode dual stack yang dilakukan pada jaringan E2E (end to end) menggunakan Wifi dan kabel menghasilkan penggunaan protocol dual stack pada jaringan E2E mampu menawarkan konektivitas jaringan stabil [8]. Pengujian transisi IPv6 juga dilakukan [6] yang melakukan penelitian tentang kinerja IPv6 dibandingkan dengan IPv4 dalam hal transfer data menggunakan protocol FTP, system pengujian menggunakan metode dual stack dan tunneling. Kesimpulan dari penelitian tersebut bahwa penggunaan FTP pada IPv6 menurunkan kinerja jaringan apabila dibandingkan dengan IPv4. Hasil penelitian ini telah menginformasikan bahwa IPv6 mempunyai delay yang lebih tinggi dibandingkan dengan IPv4 pada trafik di atas 90MB. Pada implementasi jaringan internet dengan BGP routing tentu akan sangat berpengaruh penggunaan IPv6 karena dalam global routing pasti menggunakan kapasitas yang besar. Dari beberapa sumber penelitian sebelumnya menghasilkan bahwa metode dual stack merupakan yang paling baik hingga saat ini untuk dapat diimplementasikan.

Quagga merupakan software routing yang paling populer digunakan untuk BGP routing. Penggunaan OS linux tidak terlalu berpengaruh terhadap kemampuan software routing dan penggunaan quagga menunjukkan hasil yang lebih konsisten dalam menangani routing interior [17]. Quagga dapat menjadi alternative yang sangat berguna bagi professional jaringan yang menyediakan platform routing yang dapat dimodifikasi, ada banyak komunitas yang mendukung pengembangannya mulai dari peneliti dan vendor perangkat yang saling berkontribusi dari sisi dokumentasi, pengembangan dan review sehingga mempercepat apabila ada update dan perbaikan [18]. Dalam pemilihan hardware atau software routing terutama untuk BGP sangat bergantung pada kemampuan dalam forwarding paket dan kemampuan untuk membagi proses ke dalam banyak core processor sehingga dapat maksimal penggunaannya, dalam penelitian tentang quagga ini belum ada kesimpulan apakan quagga dapat membagi proses kerja BGP dalam banyak core processor.

Ada beberapa macam BGP routing protocol yang digunakan untuk global routing misalnya saja yang berbasis hardware cisco ios, juniper junos, mikrotik router os, Brocade Fabric os, Versatile Routing Platform (VRP) dan yang berbasiskan software open source menggunakan quagga, BIRD (Bird Internet Routing Daemon), xorp, openbgpd, vios, zebra. Quagga dan BIRD merupakan BGP routing open source berbasis software yang paling popular dan banyak 
diimplementasi di jaringan. Dalam penggunaan routing IGP (Interior Gateway Protocol) Quangga mempunyai performa yang lebih baik dibandingkan dengan BIRD [17].

IPv4 merupakan jenis pengalamatan yang digunakan di dalam protokol jaringan TCP/IP yang menggunakan protokol IP. Saat ini IPv4 digunakan sebagai standar pengalamatan di Internet maupun jaringan Intranet. IPv4 pertama kali dikembangkan pada awal tahun 1980, rancangan final protokol ini termuat dalam RFC 791 yang dikeluarkan oleh lembaga (IETF) Internet Engineering Task Force [19]. IPv4 adalah sebuah jenis pengalamatan jaringan yang digunakan di dalam protokol jaringan TCP/IP yang menggunakan protokol IPv4. Panjang totalnya adalah 32bit, dan secara teoretis dapat mengalamati hingga 4 miliar host komputer atau lebih tepatnya 4.294.967.296 host di seluruh dunia.

Paket paket data dalam protokol IPv4 dikirimkan dalam bentuk datagram. Sebuah paket IPv4 terdiri atas header IPv4 dan data (payload). Setiap paket terdiri dari beberapa field yang memiliki fungsi tersendiri dan memiliki informasi yang berbeda beda seperti ditunjukkan pada gambar 1, berikut adalah tampilan dari header IPv4.

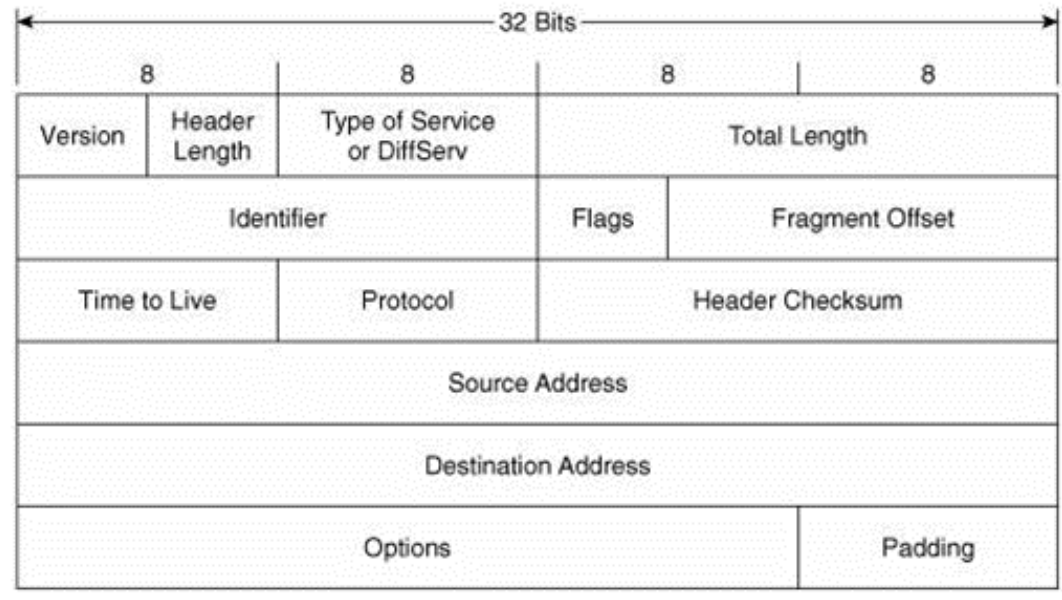

Gambar 1. IPv4 Header

Internet Protocol Versi 6 atau IPv6 merupakan protocol internet versi terbaru yang didesain untuk menggantikan IPv4 yang dirancang untuk mentransmisikan blok data yang disebut datagram dari sumber menuju tujuan dimana sumber dan tujuan telah diidentifikasi menggunakan alamat IP [20]. IPv4 sudah menuju ke masa habis sehingga dibuat protocol baru untuk menggantikannya. IPv6 memiliki kapasitas address yang sangat besar (128 bit), mendukung penyusunan address secara terstruktur, yang memungkinkan Internet terus berkembang dan menyediakan kemampuan routing baru yang tidak terdapat pada IPv4. IPv6 memiliki tipe address anycast yang dapat digunakan untuk pemilihan route secara efisien. Selain itu IPv6 juga dilengkapi oleh mekanisme penggunaan address secara local yang memungkinkan terwujudnya instalasi secara Plug \& Play atau menggunakan DHCP (Dynamic Host Configuration Protocol). Dalam DHCP IPv4 terdapat celah keamanan yang memungkinkan terjadinya serangan man the middle attack [21] sementara pada koneksi menggunakan DHCP IPv6 relatif lebih aman karena sudah secara default menggunakan IPsec yang mengenkripsi koneksi yang tidak terdapat dalam jaringan IPv4.

Salah satu kelebihan dari IPv6 terletak pada headernya dimana alamat IPv6 4 kali lebih besar daripada alamat IPv4 akan tetapi dalam header IPv6 hanya 2 kali lebih besar dari IPv4. IPv4 memiliki panjang header 20 Byte sementara IPv6 memiliki panjang 40 Byte seperti ditunjukan pada gambar 2. IPv6 memiliki 1 Fix header dan 0 atau lebih optional (extention) header. Semua informasi yang penting untuk router disimpan di dalam fix header sementara extention header berfungsi untuk membantu router untuk memahami aliran paket (packet flow). 


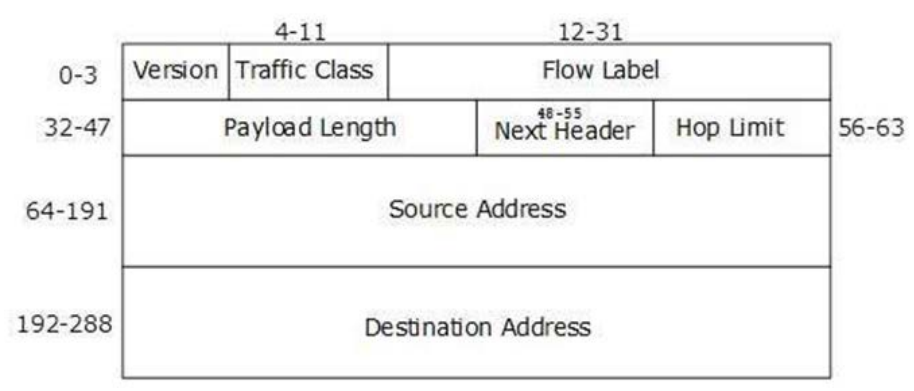

Gambar 2. Header IPv6

Routing table IPv6 memiliki infrastruktur routing yang sama dengan IPv4. Metode transisi IPv6 dengan menggunakan cara dualstack relatif lebih mudah dibanding cara metode lainnya, karena bagi administrator jaringan yang tentu saja telah mengerti bagaimana mengkonfigurasi IPv4 pada sebuah networking device, menambahkan satu protokol dan mengkonfigurasinya tentu saja akan lebih mudah. Logika routing table pada sebuah network adalah sama, baik untuk protokol IPv4 maupun IPv6. Perbedaan di antara keduanya hanya sebatas perbedaan pada command, sama seperti perbedaan command untuk setiap platform Operating System yang berbeda di dalam networking device.

\section{METODE PENELITIAN}

Penelitian ini menggunakan metode eksperimen yang digunakan untuk menunjukan kinerja quagga dalam menangani routing table IPv4 dan IPv6 dalam routing BGP. Menurut [22] pada umumnya, penelitian eksperirnental dilakukan dengan menempuh langkah-langkah seperti berikut:

a. Melakukan kajian secara induktif yang berkait erat dengan permasalahan yang hendak dipecahkan.

b. Mengidentifikasi dan mendefinisikan masalah.

c. Melakukan studi literatur dan beberapa sumber yang relevan, memformulasikan hipotesis penelitian, menentukan variabel, dan merumuskan definisi operasional dan definisi istilah.

d. Membuat rencana penelitian.

Beberapa penelitian sebelumnya [16] [8][6] lebih banyak berfokus dalam pengukuran berdasarkan QOS (quality of service) dengan parameter seperti delay, packet loss, jitter akan tetapi dalam penelitian ini menggunakan parameter yang berbeda yaitu dengan parameter waktu konvergensi, konsumsi CPU dan konsumsi memori. Adapun alur penelitian yang akan dilakukan adalah sebagai sebagai berikut seperti pada Gambar 3. 
Citec Journal, Vol. 5, No. 1, November 2017 - Januari 2018

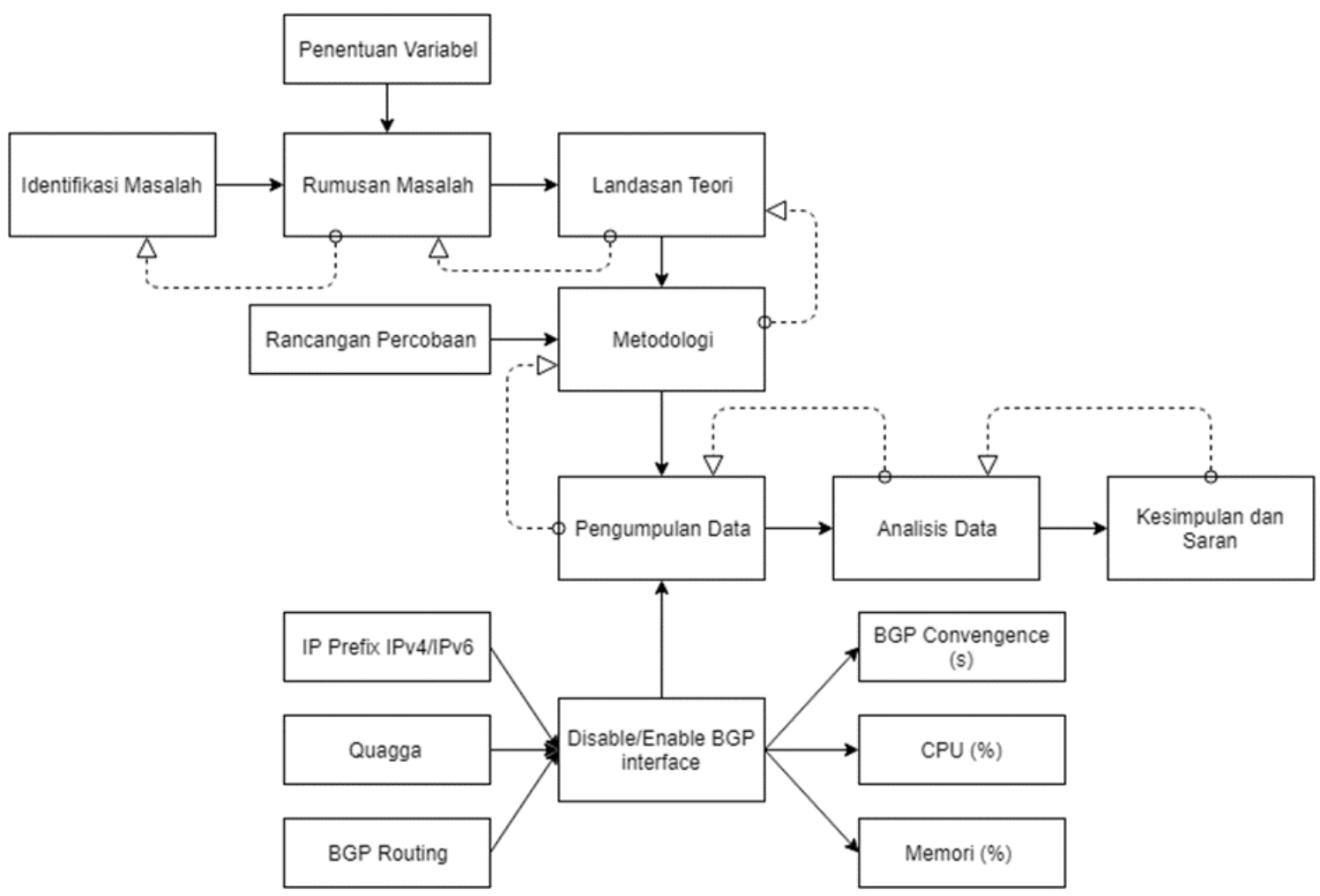

Gambar 3. Alur Rencana Penelitian

Dari perumusan masalah yang dikemukakan di atas apabila dilihat dari pendekatan penelitian menggunakan metode penelitian kuantitatif. Menurut [23] dalam penelitian kuantitatif masalah yang harus dibawa oleh peneliti sudah jelas. Masalah yang dihadapi adalah dengan adanya IPv4 yang mendekasi habis dan bagaimana melakukan transisi IPv6 dalam jaringan global menggunakan routing BGP. Setelah masalah diidentifikasi, dan dibatasi maka selanjutnya masalah tersebut dirumuskan. Setelah itu akan dilakukan pengumpulan data untuk memperoleh data yang akurat. Setelah data terkumpul nantinya akan dilakukan analisis untuk menjawab rumusan masalah yang diajukan.

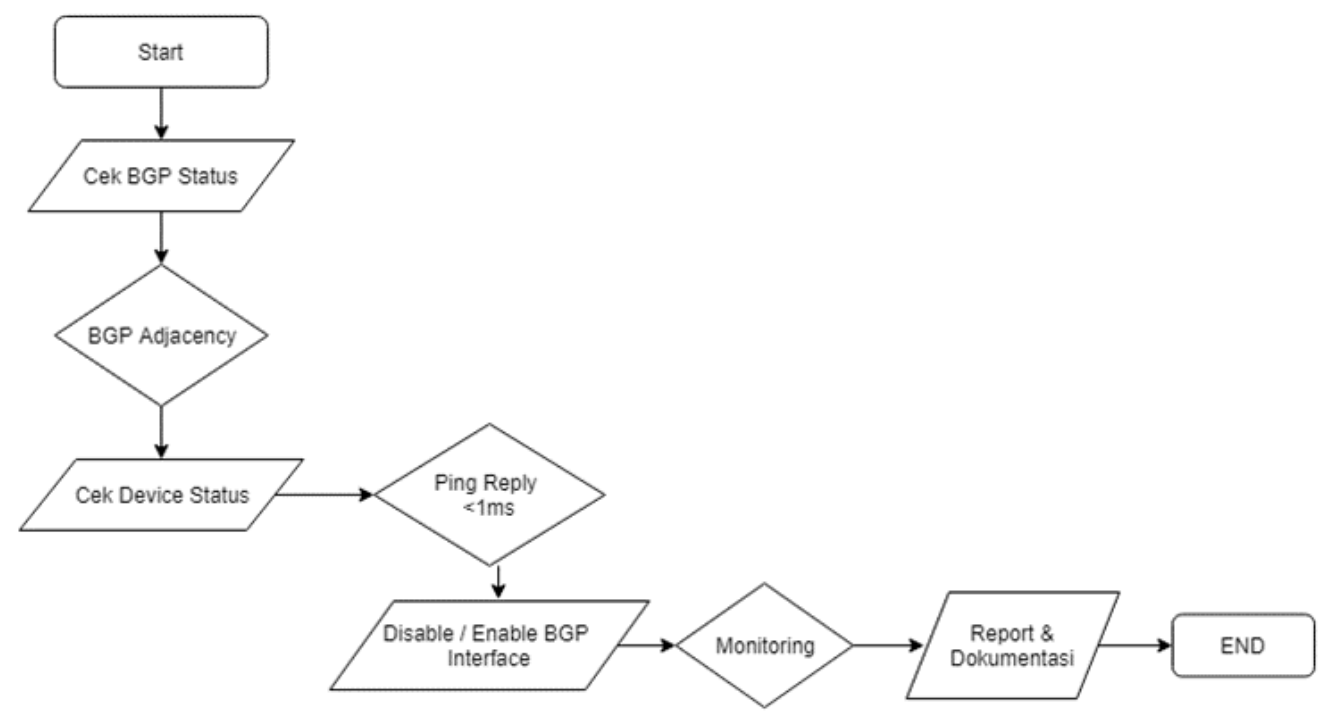

Gambar 4. Alur Pengujian 
Dalam pengumpulan data untuk mengukur kinerja jaringan akan digunakan menggunakan parameter pengukuran tentang waktu konvergensi $B G P$, persentase penggunaan memori dan CPU. Pengumpulan data waktu konvergensi BGP dilakukan dengan melakukan uji terhadap BGP routing table IPv4 dan IPv6. Flowchart pengumpulan data penelitian dapat dilihat pada Gambar 4.

Untuk monitoring tools yang digunakan menggunakan Glances dan Htop yang merupakan monitoring tool yang popular dipakai untuk monitoring perangkat secara real, sebelumnya monitoring tools telah dilakukan uji terhadap validitas keluaran data yang dihasilkan. Pengujian validitas tools dilakukan dengan melakukan perbandingkan data yang dihasilkan dari CPU dan memori real dalam perangkat tersebut dan hasil saat menggunakan monitoring tools. Hal ini digunakan untuk memastikan bahwa penggunaan monitoring tools mencapai hasil yang sama dengan kondisi real perangkat. Spesifikasi perangkat router yang digunakan untuk pengujian ditunjukkan pada Tabel 1.

Tabel 1. Spesifikasi Hardware Router

\begin{tabular}{|l|l|}
\hline Hardware Router & HP ProLiant DL20G9-25A \\
\hline Platform & Single CPU Rack Server \\
\hline Processor Type & Intel ${ }^{\circledR}$ Xeon Processor E3-1230v6 (4 Cores, 3.50 GHz, 8MB Cache) \\
\hline Chipset & Intel ${ }^{\circledR}$ C232 Chipset E3-1200 Series \\
\hline Standard Memory & $1 \times 16 G B$ UIMM DDR4 PC4-2400 \\
\hline Hard Drive & $1 \times 1 T B$ SATA 7.2K RPM 3.5" LFF Non Hot Plug \\
\hline Networking & $2 \times$ Integrated Gigabit Ethernet \\
\hline Chassis Form Factor & Rackmount 1U Case \\
\hline Power Supply Type & $290 W$ \\
\hline
\end{tabular}

Setelah data berhasil dikumpulkan selanjutnya akan dilakukan analisis, analisis data dilakukan dengan cara melakukan rata-rata terhadap data hasil dari pengumpulan data yang masih berupa data mentah. Dari hasil pengumpulan data tes menggunakan table routing yang dilakukan sebanyak 10 kali pengetesan menggunakan metode dual stack akan diperoleh waktu konvergensi yang kemudian dilakukan rata rata terhadap hasil tes sehingga didapatkan hasil yang paling stabil. Data waktu konvergensi akan menunjukkan berapa lama waktu routing BGP quagga untuk dapat menerima seluruh table routing. Selain waktu konvergensi akan diperoleh juga data tentang persentase konsumsi $C P U$ dan Memori, data tersebut juga akan dilakukan rata-rata untuk memperoleh hasil persentase konsumsi $C P U$ dan memori yang paling stabil.

\section{HASIL DAN PEMBAHASAN}

Dari hasil pengujian dengan melakukan percobaan eksperimen sebanyak 10 kali yang dilakukan dengan menggunakan parameter BGP Convergence, konsumsi penggunaan CPU dan konsumsi penggunaan memori maka diperoleh hasil sebagai berikut.

\subsection{BGP Convergence Time}

BGP convergence merupakan waktu yang dibutuhkan BGP dalam setiap sesi untuk melakukan routing table update secara sempurna. Percobaan ini dilakukan dengan melakukan monitoring dari proses BGP hidup sampai menerima semua tabel routing. Dari hasil percobaan sebanyak 10 kali menghasilkan nilai yang dapat dilihat pada Tabel 2. 
Citec Journal, Vol. 5, No. 1, November 2017 - Januari 2018

ISSN: 2460-4259

Tabel 2. Hasil Percobaan BGP Convergence Time

\begin{tabular}{|c|c|c|c|c|c|c|c|c|c|c|c|c|c|}
\hline Percobaan & 1 & 2 & 3 & 4 & 5 & 6 & 7 & 8 & 9 & 10 & Min & Max & $\bar{X}$ \\
\hline BGP Peer 1 & 17 & 22 & 17 & 17 & 22 & 15 & 16 & 20 & 16 & 18 & 16 & 22 & 18 \\
\hline BGP Peer 2 & 28 & 29 & 31 & 34 & 31 & 34 & 30 & 24 & 28 & 27 & 24 & 34 & 29,6 \\
\hline BGP Peer 3 & 45 & 40 & 42 & 35 & 43 & 44 & 41 & 41 & 40 & 38 & 35 & 45 & 40,9 \\
\hline BGP Peer 4 & 47 & 49 & 48 & 50 & 51 & 51 & 52 & 48 & 54 & 51 & 48 & 52 & 50,1 \\
\hline BGP Peer 5 & 62 & 62 & 61 & 60 & 60 & 61 & 61 & 60 & 60 & 62 & 60 & 62 & 60,9 \\
\hline BGP Peer 6 & 69 & 68 & 66 & 72 & 72 & 66 & 64 & 69 & 67 & 66 & 64 & 69 & 67,9 \\
\hline BGP Peer 7 & 82 & 80 & 82 & 81 & 82 & 76 & 73 & 77 & 82 & 82 & 73 & 82 & 79,7 \\
\hline BGP Peer 8 & 87 & 83 & 92 & 83 & 92 & 91 & 88 & 95 & 90 & 92 & 83 & 92 & 89,3 \\
\hline BGP Peer 9 & 97 & 99 & 93 & 98 & 101 & 100 & 96 & 100 & 104 & 94 & 94 & 101 & 98,2 \\
\hline BGP Peer 10 & 101 & 105 & 109 & 109 & 111 & 102 & 104 & 105 & 111 & 109 & 102 & 111 & 106,6 \\
\hline
\end{tabular}

Pada penelitian [10] waktu konvergensi $B G P$ dalam percobaanya mendapatkan hasil ratarata 0-31 second dalam 1 BGP peer. Sementara dari penelitian ini untuk 1 BGP peer mendapatkan hasil yang lebih baik dengan minimal 15 second dan maksimal 22 second dengan nilai akurasi kurang dari 10 second sementara nilai akurasi dari penelitian sebelumnya kurang dari 31 second. Untuk nilai total peningkatan akurasi dalam keseluruhan percobaan sebesar 2-10 second. Hal ini dimungkinkan dikarenakan pengaruh dari faktor eksternal misalkan spesifikasi hardware router dan faktor internal misalkan BGP system yang digunakan. Setelah mendapatkan hasil dari pengujian BGP Convergence Time kemudian dilakukan rata-rata yang menghasilkan grafik seperti dapat dilihat pada Gambar 5.

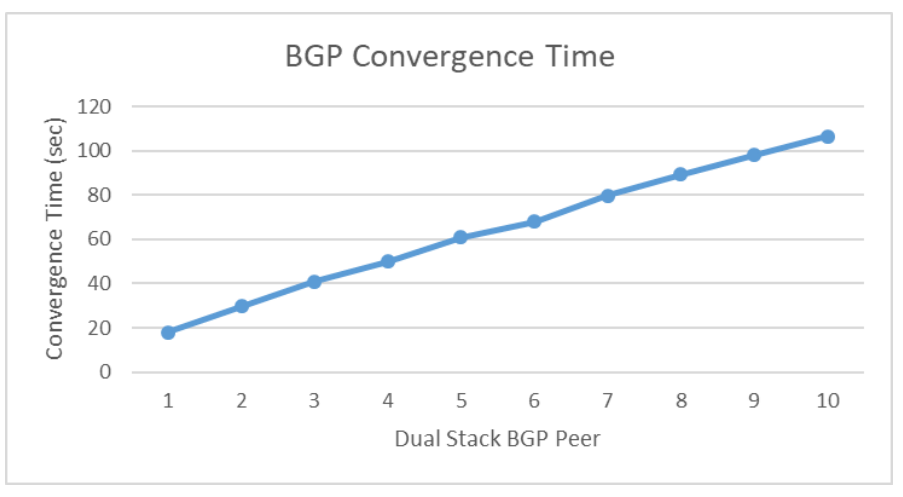

Gambar 5. Rata-rata BGP Convergence Time

Dari hasil percobaan waktu konvergensi BGP dilihat pada gambar 5 bahwa rata-rata peer 1 lama waktunya 18 second, Peningkatan waktu konvergensi pada masing masing peer misalkan dari peer 1 ke peer 2 dan selanjutnya mendapatkan hasil minimal 7 second dan maksimal 11,8 second. Pada penggunaan 10 BGP peer menghasilkan waktu konvergensi rata-rata 106,6 detik. Dalam percobaan ini setiap penambahan BGP peer selalu berbanding lurus dengan meningkatnya waktu konvergensi.

\subsection{Konsumsi penggunaan CPU (\%)}

Konsumsi penggunaan CPU diambil dari penggunaan CPU maksimal yang dibutuhkan $B G P$ dalam setiap sesi. Pengujian dengan melakukan percobaan sebanyak 10 kali uji terhadap CPU menghasilkan nilai yang dapat dilihat pada Tabel 3. 
Tabel 3. Hasil Percobaan Konsumsi Penggunaan CPU

\begin{tabular}{|l|c|c|c|c|c|c|c|c|c|c|c|c|c|}
\hline Percobaan & 1 & 2 & 3 & 4 & 5 & 6 & 7 & 8 & 9 & 10 & Min & Max & $\bar{X}$ \\
\hline BGP Peer 1 & 12,3 & 13,2 & 13,3 & 12,4 & 12,3 & 12,3 & 13,1 & 11 & 13,1 & 12,3 & 11 & 13,3 & 12,53 \\
\hline BGP Peer 2 & 15 & 14,2 & 14,5 & 14,3 & 15,1 & 14,8 & 14,2 & 14,5 & 13,9 & 14,5 & 13,9 & 15,1 & 14,5 \\
\hline BGP Peer 3 & 17,7 & 17,6 & 18 & 17,6 & 16,8 & 17,4 & 19,2 & 16,4 & 17,7 & 19,1 & 16,4 & 19,2 & 17,75 \\
\hline BGP Peer 4 & 20,4 & 19,3 & 18,9 & 19,3 & 19,4 & 20 & 18,8 & 20,3 & 20,7 & 20,5 & 19,4 & 20,7 & 19,76 \\
\hline BGP Peer 5 & 23,3 & 23,2 & 23,9 & 22,2 & 24,2 & 20,7 & 20,1 & 20,9 & 22,5 & 20,1 & 20,1 & 23,2 & 22,11 \\
\hline BGP Peer 6 & 21,1 & 22,8 & 20,6 & 17,7 & 18,9 & 19 & 20,4 & 19,6 & 18,7 & 19,2 & 17,7 & 22,8 & 19,8 \\
\hline BGP Peer 7 & 19,5 & 20,4 & 22,7 & 19 & 19,9 & 19 & 19,5 & 20,7 & 18,6 & 19,2 & 18,6 & 22,7 & 19,85 \\
\hline BGP Peer 8 & 19,7 & 18 & 19,5 & 19,4 & 20,4 & 18,2 & 19,6 & 18,9 & 20,2 & 19,2 & 18 & 20,4 & 19,31 \\
\hline BGP Peer 9 & 18 & 19,2 & 19,7 & 18,2 & 17,8 & 17,9 & 19,2 & 17,5 & 18,2 & 19 & 17,5 & 19,7 & 18,47 \\
\hline BGP Peer 10 & 19,4 & 18,3 & 18,7 & 18 & 18,4 & 19 & 19 & 17,8 & 18,1 & 18,7 & 17,8 & 19,4 & 18,54 \\
\hline
\end{tabular}

Dalam penelitian [7] menghasilkan bahwa metode dual stack meingkatkan penggunaan konsumsi CPU dan memori akan tetapi dalam papernya tidak menghasilkan data yang mendukung kesimpulan tersebut dan [17] dalam pengukuran interior routing performance telah menginformasikan tentang kinerja berdasarkn CPU akan tetapi tidak ada informasi tertulis yang lengkap tentang hasil dari pengujian. Dari penelitian ini menghasilkan konsumsi penggunaan CPU seperti pada tabel 3. Percobaan yang dilakukan dengan parameter CPU mendapatkan nilai akurasi antara 1,2-5,1\% second, akurasi terendah didapatkan pada saat peer ke 6. Setelah mendapatkan hasil dari pengujian konsumsi penggunaan CPU, kemudian dilakukan rata-rata yang menghasilkan grafik seperti dapat dilihat pada Gambar 6.

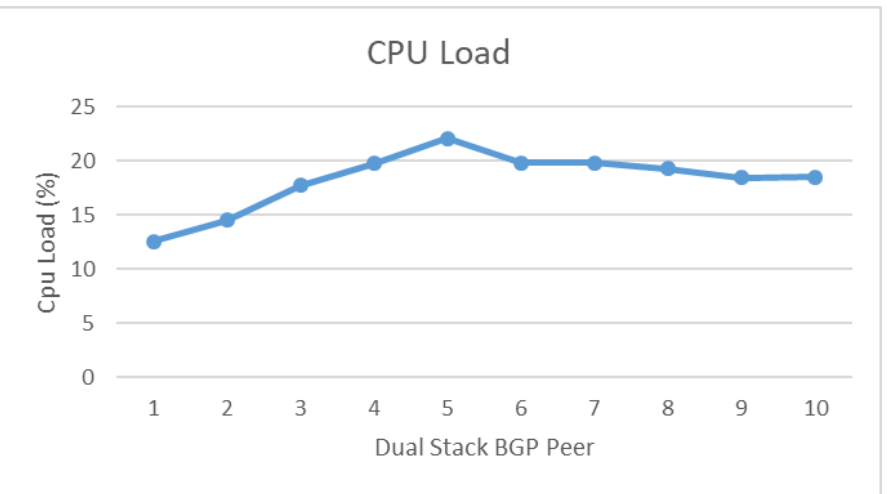

Gambar 6. Rata-rata konsumsi penggunaan CPU

Dari hasil percobaan dapat diketahui bahwa dalam 1 BGP peer membutuhkan rata-rata konsumsi CPU maksimal sebesar 12,53\%. Dari gambar 10 dapat dilihat bahwa penggunaan CPU memperoleh hasil maksimal pada saat penggunaan 5 BGP peer yang kemudian pada saat peer 610 memperoleh hasil rata-rata $15-20 \%$. Hal ini kemungkinan terjadi antrian pemrosesan IP didalam CPU karena dengan semakin banyak IP dalam kondisi tertentu tidak selalu meningkatkan CPU proses. Perbedaannya adalah dari peer 1-5 mendapatkan kecepatan CPU yang paling maksimal sementara pada peer 6-10 terjadi pemrosesan yang lebih lambat disbanding sebelumnya. Rata-rata peningkatan CPU misalkan dari peer 1 ke peer 2 dan selanjutnya sebesar 2,31\% dan nilai maksimal 3,25\%. Hasil minus diakibatkan karena penambahan peer tidak selalu berbanding lurus dengan maksimal konsumsi CPU. Pada percobaan ini dapat menjadi temuan baru tentang proses CPU yang terjadi pada saat BGP melakukan update tabel routing. 
Citec Journal, Vol. 5, No. 1, November 2017 - Januari 2018

ISSN: 2460-4259

\subsection{Konsumsi penggunaan memori (\%)}

Konsumsi penggunaan memori diambil dari penggunaan memori maksimal yang dibutuhkan BGP dalam setiap sesi. Dari hasil percobaan sebanyak 10 kali menghasilkan nilai yang dapat dilihat pada Tabel 4.

Tabel 4. Hasil Percobaan Konsumsi Penggunaan Memori

\begin{tabular}{|l|r|r|r|r|r|r|r|r|r|r|r|r|r|}
\hline Percobaan & 1 & 2 & 3 & 4 & 5 & 6 & 7 & 8 & 9 & 10 & Min & Max & $\bar{X}$ \\
\hline BGP Peer 1 & 7,1 & 6,7 & 7,1 & 7,1 & 7,1 & 6,7 & 7,1 & 6,7 & 6,7 & 6,7 & 6,7 & 7,1 & 6,9 \\
\hline BGP Peer 2 & 8,1 & 8,1 & 8,1 & 8,1 & 8,1 & 8,1 & 8,1 & 8,1 & 8,1 & 8,1 & 8,1 & 8,1 & 8,1 \\
\hline BGP Peer 3 & 9,1 & 9,1 & 9,1 & 9,1 & 9,1 & 9,1 & 8,8 & 9,1 & 9,1 & 9,6 & 8,8 & 9,6 & 9,12 \\
\hline BGP Peer 4 & 10 & 10,1 & 10,7 & 10,6 & 9,4 & 9,4 & 9,5 & 9,4 & 9,4 & 9,4 & 9,4 & 10,7 & 9,79 \\
\hline BGP Peer 5 & 10 & 10,4 & 10,7 & 10,7 & 10,7 & 10,7 & 10,7 & 10,7 & 10,7 & 10,7 & 10 & 10,7 & 10,6 \\
\hline BGP Peer 6 & 11 & 11 & 11 & 11,4 & 11 & 11 & 11 & 11,2 & 11,3 & 11 & 11 & 11,4 & 11,09 \\
\hline BGP Peer 7 & 12,1 & 12,4 & 12,6 & 12,5 & 12,8 & 12,9 & 12,6 & 12,1 & 12,3 & 12,3 & 12,1 & 12,8 & 12,46 \\
\hline BGP Peer 8 & 14 & 14,2 & 14,2 & 14,1 & 13,8 & 14,2 & 14,1 & 14 & 14,1 & 14,1 & 13,8 & 14,2 & 14,08 \\
\hline BGP Peer 9 & 15,2 & 15,1 & 15,2 & 15,2 & 15,2 & 15 & 15 & 15,4 & 15,4 & 15,4 & 15 & 15,4 & 15,21 \\
\hline BGP Peer 10 & 16,6 & 16,6 & 16,6 & 16,6 & 16,1 & 16,4 & 16,4 & 16,4 & 16,4 & 16,4 & 16,1 & 16,6 & 16,45 \\
\hline
\end{tabular}

Dalam pengujian terhadap penggunaan memori dapat diketahui bahwa nilai akurasi terhadap hasil percobaan adalah $0-1,3 \%$. Nilai akurasi tertinggi pada saat peer 2 yaitu $0 \%$ mengindikasikan hasil yang stabil sementara pada peer ke 4 mendapatkan akurasi terendah sebesar 1,3\%. Setelah mendapatkan hasil dari pengujian konsumsi penggunaan memori, kemudian dilakukan rata-rata yang menghasilkan grafik seperti dapat dilihat pada Gambar 7.

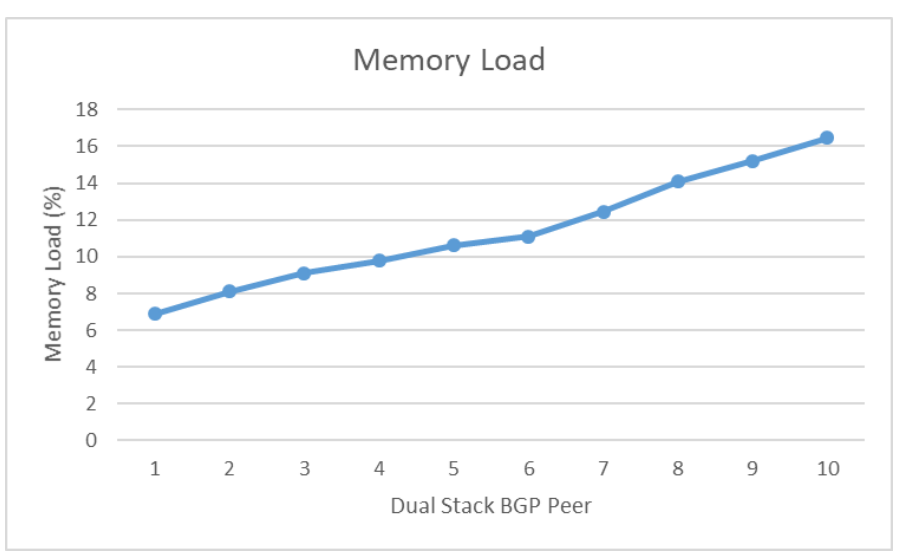

Gambar 7. Rata-rata konsumsi penggunaan memori

Dari hasil percobaan dapat diketahui bahwa dalam peer ke 1 membutuhkan rata-rata konsumsi memori sebesar 6,9\% dan konsumsi memori tertinggi pada saat peer ke 10 sebesar 16,6\%. Peningkatan konsumsi memori dari peer 1 ke peer 2 dan selanjutnya adalah sebesar 0,491,62\%. Peningkatan memori minimal terjadi pada peer ke 3 dan peningkatan memori maksimal pada peer ke 7. Dari Gambar 7 dapat dilihat bahwa semakin banyak peer berbanding lurus dengan peningkatan konsumsi memori. Hal ini sangat relevan dimana memori menyimpan seluruh tabel routing dengan semakin banyak tabel routing tentunya meningkatkan konsumsi memori. 


\section{KESIMPULAN}

Dari hasil penelitian ini dapat disimpulkan bahwa penggunaan metode dual stack dalam kinerja yang baik digunakan untuk melakukan implementasi IPv6. Dengan asumsi bahwa perusahaan penyedia internet mempunyai minimal 2 BGP peer masih dalam kategori yang baik dikarenakan hasil penelitian menunjukkan untuk menerima seluruh table routing 29 second, konsumsi penggunaan CPU maksimal 14,2\% dan memori 8,1\% menunjukkan hasil yang sangat baik. Kinerja CPU mendapatkan hasil paling maksimal pada saat menggunakan 5 BGP peer dengan penggunaan CPU rata-rata sebesar 22,11\%. Sementara apabila mempunyai 10 BGP peer, router membutuhkan waktu 106,6 detik atau kurang lebih 1 menit 7 detik dengan konsumsi CPU maksimal 18,54\% dan konsumsi memori 16,45\% untuk dapat menerima seluruh table routing dan trafik internet dapat berjalan dengan baik. BGP convergence time dan konsumsi memori berbanding lurus dengan peningkatan jumlah peer sementara konsumsi CPU tidak selalu berbanding lurus dengan jumlah peer. Hasil tersebut menunjukkan software routing quagga sangat baik untuk diimplementasikan untuk transisi BGP IPv6 menggunakan metode dualstack.

\section{SARAN}

Penelitian selanjutnya dapat dilakukan dengan menggunakan routing software yang lain sehingga dapat diketahui routing software mana yang lebih baik dalam menangani routing table. Dari percobaan dengan parameter CPU ditemukan bahwa peningkatan jumlah peer tidak selalu berbanding lurus terhadap peningkatan CPU sehingga perlu adanya penelitian lebih lanjut terkait fenomena tersebut karena penelitian ini melihat bahwa walaupun konsumsi CPU lebih rendah akan tetapi dalam rentang proses CPU mempunyai waktu yang lebih lama.

\section{DAFTAR PUSTAKA}

[1] Nordrum, A., 2016, The Internet of Fewer Things. IEEE Spectrum. https://spectrum.ieee.org/telecom/internet/the-internet-of-fewer-things, diakses pada tanggal 15 February 2018

[2] Huston, G., 2015, IPv4 Address Exhaustion in APNIC. Apnic. https://blog.apnic.net/2015/08/07/ipv4-address-exhaustion-in-apnic/. Diakses pada tanggal 25 February 2018.

[3] Wilson, P., 2018, How bad is IPv4 address exhaustion? Apnic. https://blog.apnic.net/2018/02/15/bad-ipv4-address-exhaustion/. Diakses pada tanggal 1 Maret 2018.

[4] Permenkominfo, 2014. Kebijakan Roadmap Penerapan IPv6 di Indonesia. Kominfo. https://jdih.kominfo.go.id/produk_hukum/abstrak/33.

[5] Apnic, 2018, Use of IPv6 for World (XA). Apnic. https://stats.labs.apnic.net/ipv6/XA. Diakses pada tanggal 15 Februari 2018.

[6] Ismail, M. N., Afizi, M., Shukran, M., Maskat, K., Mohamed, M. H., 2013, File Transfer over Dual-Stack IPv6 Tunnelling in Real Network Environment: Router to Router Performance Analysis Using Best Effort Approach. Journal of Computer Science and Control Systems, Vol. 6, No. 2, Hal 18-24.

[7] Sookun, Y., Bassoo, V., 2016, Performance analysis of IPv4/IPv6 transition techniques. 2016 IEEE International Conference on Emerging Technologies and Innovative Business Practices for the Transformation of Societies, EmergiTech 2016: 188-93, Mauritius, 3-6 Agustus. 
Citec Journal, Vol. 5, No. 1, November 2017 - Januari 2018

[8] Mohd, W., Wan, N., Rahman, R.A., Kassim, M., Yusof, M.I., 2016, Performance Comparison Analysis of E2E Dual- Stack IP Protocol Method over Wired and Wi-Fi Broadband Access. IEEE 6th International Conference on System Engineering and Technology (ICSET), Bandung, 3-4 Oktober 2016.

[9] Bennesby, R.., Mota, E., 2017, A survey on approaches to reduce BGP interdomain routing convergence delay on the Internet. IEEE Communications Surveys and Tutorials (c), Vol. 19, No. 4, Hal 2949 - 2984.

[10] Kaushal, P., 2015, Performance and Security Analysis of Border Gateway Protocol. International Journal of Computer Science Trends and Technology (IJCST), Vol. 3, No. 4, Hal 196-207.

[11] Rekhter, Y., Li, T., Hares, S., 2006, A Border Gateway Protocol 4 (BGP-4). RFC 4271.

[12] McPherson, D., Patel, K., 2006, Experience with the BGP-4 Protocol. RFC 4277.

[13] Fahriani, N., Djanali, S., Shiddiqi, A. M., 2012. Efisiensi Rute Pada Protokol Dynamic Source Routing Menggunakan Path Aware-Short. EKSPLORA INFORMATIKA Vol. 2, No. 1, Hal 37-48.

[14] Nordmark, E., Gilligan, E., 2005. Basic Transition Mechanisms for IPv6 Hosts and Routers. RFC 4213.

[15] Durand, A., Droms, R., Woodyatt, J., Lee, Y., 2011. Dual-Stack Lite Broadband Deployments Following IPv4 Exhaustion. RFC 6333.

[16] Mukti, A. R., 2016. Studi Performa Migrasi Ipv4 Ke Ipv6 pada Metode Dual Stack. ANNUAL RESEARCH SEMINAR, Vol. 2, No.1, Hal 14 - 22.

[17] Horalek, J., Matyska, J., Sobeslav, V., 2014. Comparative analysis of software routers on Linux. IEEE International Symposium on Computational Intelligence and Informatics: 295-300.

[18] Jakma, P., Lamparter, D., 2014. Introduction to the Quagga Routing Suite. IEEE Network Vol. 28, No. 2, Hal 42-48, Doi: 10.1109/MNET.2014.6786612.

[19] Information Sciences Institute University of Southern California., 1981. INTERNET PROTOCOL. Wilson Boulevard Arlington, Virginia: RFC 791.

[20] Deering, S., Hinden, R., 1998. Internet Protocol, Version 6 (IPv6) Specification. RFC 2460.

[21] Kadafi, M., Khusnawi, K., 2015. Analisis Rogue DHCP Packets Menggunakan Wireshark Network Protocol Analyzer. Creative Information Technology Journal, Vol. 2, No. 2, Hal 165-80.

[22] Sukardi., 2003. Metodologi Penelitian Pendidikan Kompetensi dan Praktiknya, Bumi Aksara, Jakarta.

[23] Sugiyono., 2011. Metode Penelitian Kuantitatif, Kualitatif, dan R\&D. Alfabeta, Bandung. 